\title{
In Vitro Evaluation of Fungicides against Alternaria macrospora Causing Leaf Spot in Cotton
}

\author{
B. Mohan Venkata Siva Prasad ${ }^{1}$, S. L. Bhattiprolu ${ }^{2 *}$, \\ V. Prasanna Kumari ${ }^{1}$ and P. Anil Kumar ${ }^{1}$ \\ ${ }^{1}$ Department of Plant Pathology, Bapatla - 522 101, Andhra Pradesh, India \\ ${ }^{2}$ Regional Agricultural Research Station, Lam, Guntur - 522 034, Andhra Pradesh, India \\ *Corresponding author
}

\section{A B S T R A C T}

\begin{tabular}{|l|}
\hline Key w or d s \\
Alternaria \\
macrospora, Cotton \\
leaf spot, \\
Fungicides
\end{tabular}

Keywords

Alternaria

macrospora, Cotton

leaf spot,

Fungicides

\section{Introduction}

Cotton (Gossypium spp.) is the most important commercial crops of the world, which belongs to the botanical family Malvaceae. Cotton is referred to as "King of Fibres" and also known as "White Gold". India is the largest cotton growing country in the world with an area around $10.5 \mathrm{M}$ ha followed by United States and China. The cotton production of India is 35.1 million bales and productivity is $568 \mathrm{~kg}$ $\mathrm{ha}^{-1}$. India's share in global cotton exports is around 25\%. In India, Andhra Pradesh stands seventh in area with 4.49 lakh ha, eighth in production with 13.10 lakh bales and second in productivity with $719 \mathrm{~kg} \mathrm{ha}^{-1}$ during 201617 (AICCIP, 2017).

Cotton crop is affected by fungal, bacterial and viral diseases. Among fungal diseases, leaf spot/blight caused by Alternaria macrospora Zimm., is the most commonly occurring disease in Andhra Pradesh.

Under congenial conditions the disease causes severe defoliation, cracking and breaking of stems and reduction in boll formation. The disease caused losses to the tune of $38.23 \%$ in 
LRA 5166 (Bhattiprolu and Prasada Rao, 2009) and $33.43 \%$ in Jayadhar (Chattannavar et al., 2010). Based on the importance of Alternaria and its regular occurrence in Andhra Pradesh, the present investigation was carried out with a view to find out the efficacy of fungicides against $A$. macrospora.

\section{Materials and Methods}

\section{Effect of Fungicides on fungal growth}

The details of fungicides evaluated against $A$. macrospora are given under Table 1. All the fungicides were tested at three concentrations (with recommended dose, 500 ppm below their recommended dose and $500 \mathrm{ppm}$ above their recommended dose) on active ingredient basis. Thus the fungicides @ $0.3 \%$ were tested at 2500, 3000 and 3500 ppm and those @ $0.2 \%$ tested at 1500, 2000 and 2500 ppm and the fungicides @ 0.1\% tested at 500,1000 and 1500 ppm.

Selected fungicides were evaluated in vitro against $A$. macrospora by employing poisoned food technique (Nene and Thapliyal, 1993). Ten $\mathrm{ml}$ stock solution of $1,00,000 \mathrm{ppm}$ concentration was prepared in sterilized distilled water. The desired concentration of fungicide in the medium was obtained by using the formula:

$\mathrm{C}_{1} \mathrm{~V}_{\mathrm{I}}=\mathrm{C}_{2} \mathrm{~V}_{2}$

Where,

$\mathrm{C}_{1}=$ concentration of the stock solution (ppm)

$\mathrm{V}_{1}=$ volume of the stock solution to be added $(\mathrm{ml})$

$\mathrm{C}_{2}=$ desired concentration $(\mathrm{ppm})$

$\mathrm{V}_{2}=$ volume of PDA in which fungicide is to be amended $(\mathrm{ml})$
Twenty $\mathrm{ml}$ of the poisoned medium was poured in to sterilized Petri plate $(9.0 \mathrm{~cm}$ diameter) under aseptic conditions in Laminar air flow inoculation chamber and allowed to solidify. Each plate was inoculated in the centre with five $\mathrm{mm}$ diameter disc cut from the periphery of actively growing seven days old A. macrospora culture under aseptic conditions and incubated at $28 \pm 1{ }^{\circ} \mathrm{C}$ in a BOD incubator. Three replications were maintained for each treatment. PDA plates containing non poisoned medium inoculated with $A$. macrospora served as control. Radial growth of A. macrospora was recorded daily in control plate starting from the initiation of the fungal growth in correspondence to treatment plates until full growth of fungus was obtained in control. Per cent inhibition of growth over control was calculated using the formula given by Vincent (1927).

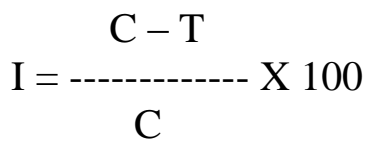

Where,

$\mathrm{I}=$ per cent inhibition.

$\mathrm{C}=$ growth of $A$. macrospora in non-poisoned food medium.

$\mathrm{T}=$ growth of $A$. macrospora in poisoned food medium.

\section{Results and Discussion}

All the fungicides at three concentrations tested significantly reduced radial growth of A. macrospora compared to check $(9.00 \mathrm{~cm})$ (Table 2). Mancozeb, carbendazim, hexaconazole, propiconazole and carbendazim + mancozeb completely inhibited the growth of the pathogen at three test concentrations. Decrease in radial growth with increased concentration was observed among the other 
fungicides viz., captan + hexaconazole, thiram and captan with a mean radial growth of 0.92 $\mathrm{cm}, 1.9 \mathrm{~cm}$ and $1.9 \mathrm{~cm}$, being significantly superior followed by copper oxychloride (COC) and chlorothalonil with $2.21 \mathrm{~cm}$ and $2.48 \mathrm{~cm}$ mean radial growth. The significantly least effective fungicide was azoxystrobin with a mean radial growth of $3.89 \mathrm{~cm}$ (Table 2 and Plate 1).
Significant decrease with increase in concentration was recorded with all fungicides with the least radial growth at $>500 \mathrm{ppm}$ of recommended dose $(1.02 \mathrm{~cm})$ and the highest at $<500 \mathrm{ppm}$ of recommended dose $(1.41 \mathrm{~cm})$.

The mean radial growth for each concentration was significantly lesser than that of the next higher concentration (Fig. 1).

Fig.1 Effect of fungicides on growth of Alternaria macrospora in vitro

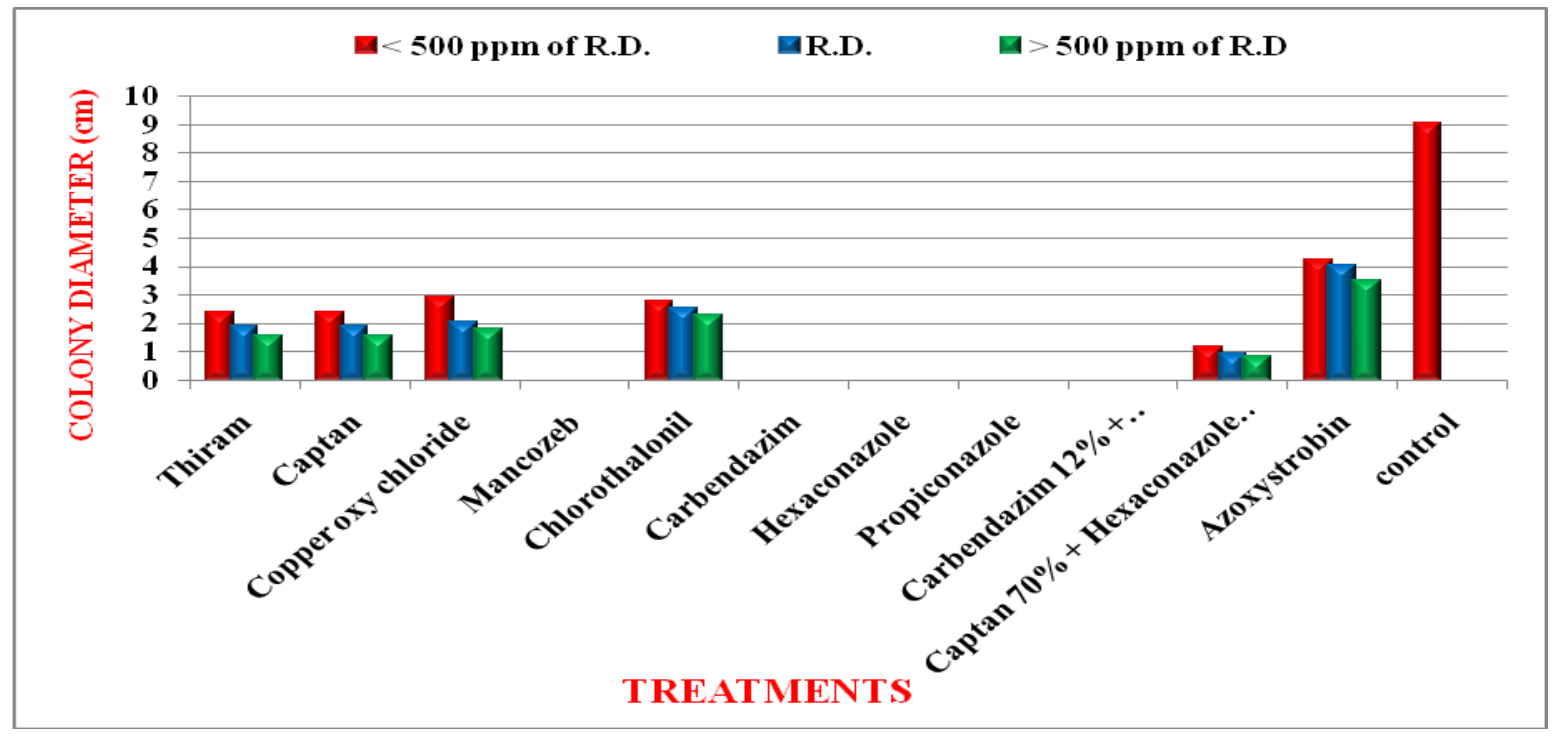

Fig.2 Effect of fungicides on per cent growth inhibition of Alternaria macrospora in vitro

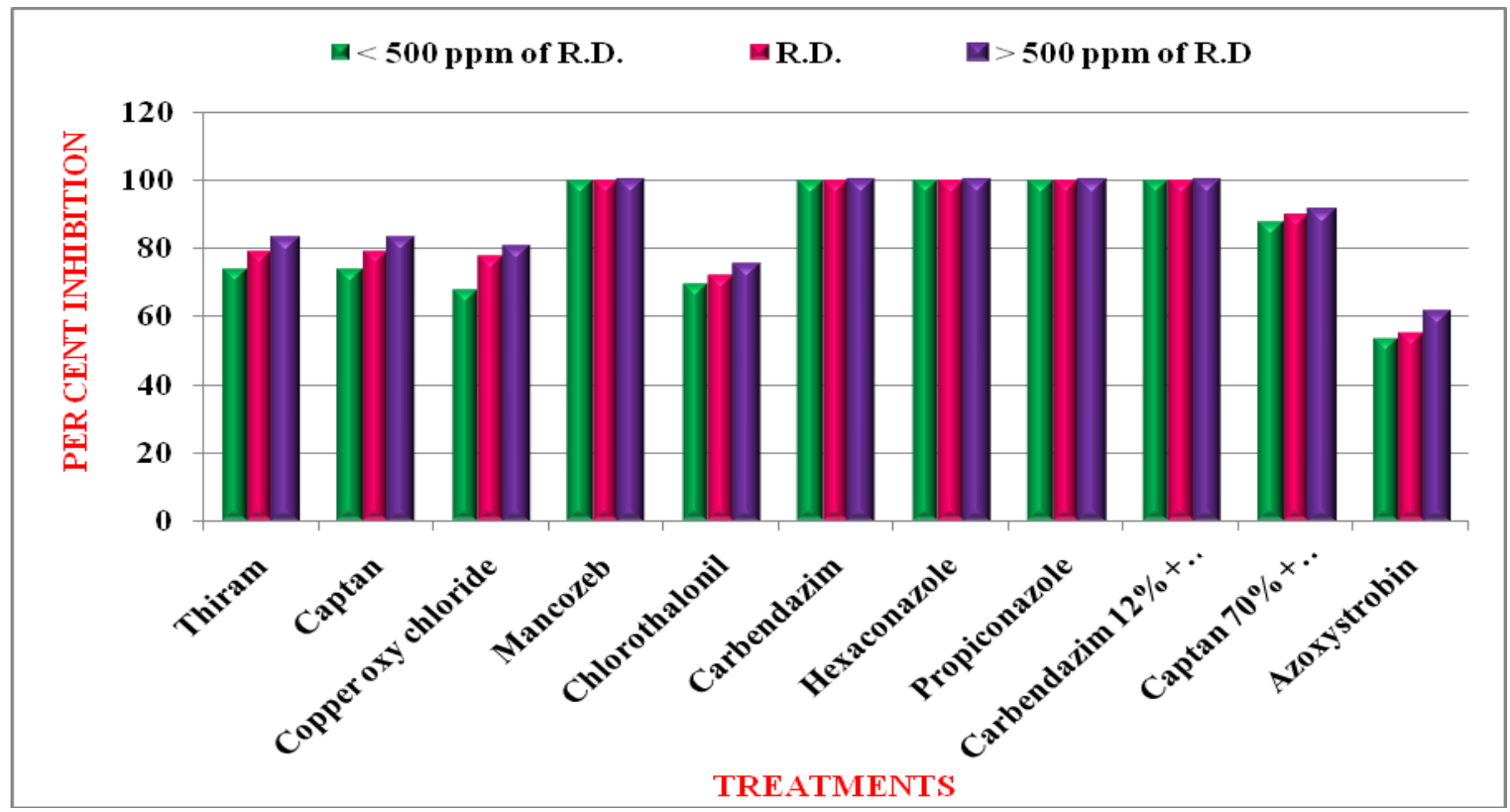


Plate.1 Effect of fungicides on radial growth of Alternaria macrospora
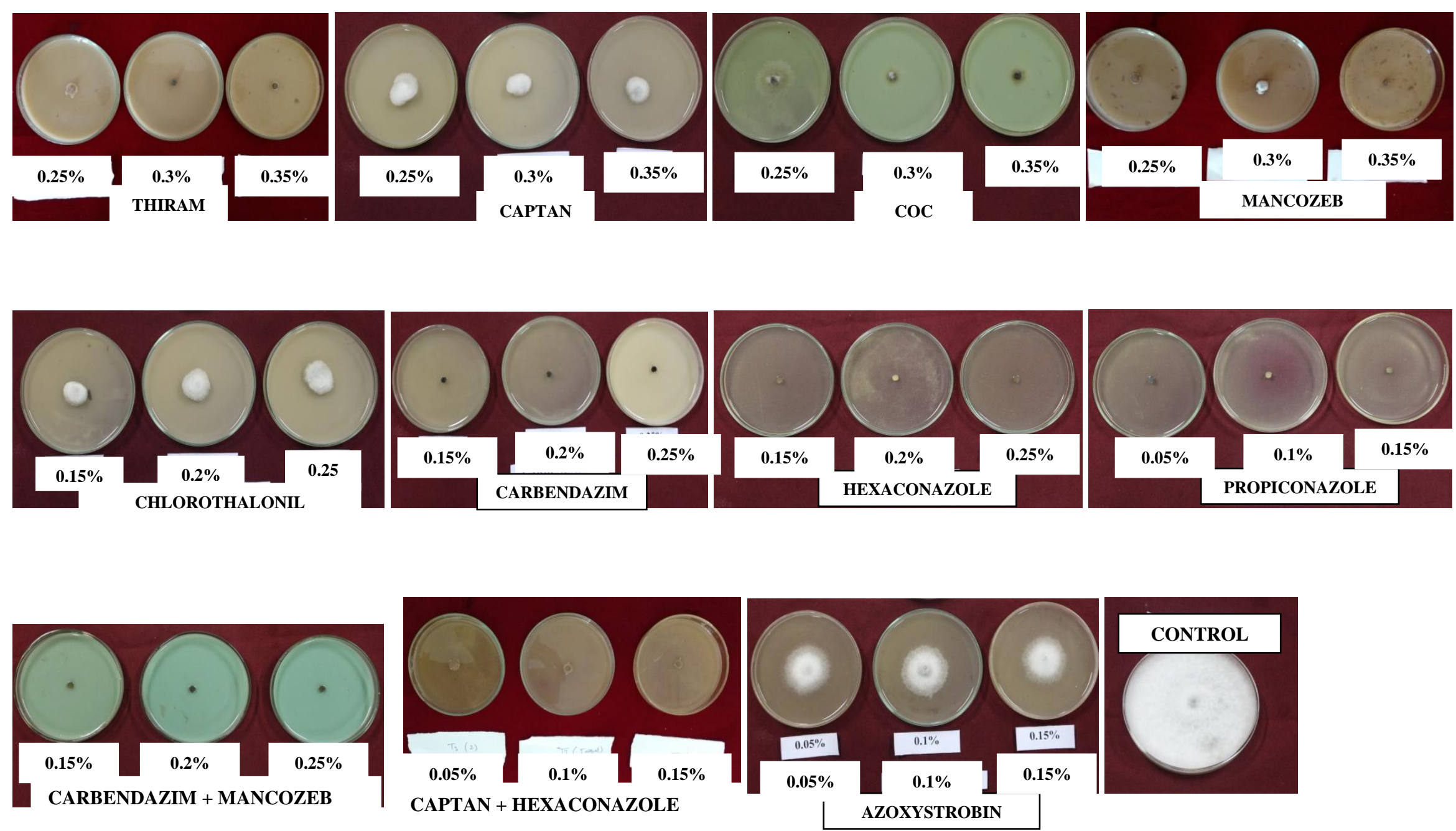

CAPTAN + HEXACONAZOLE 
Table.2 In vitro evaluation of fungicides at different concentrations against Alternaria macrospora

\begin{tabular}{|c|c|c|c|c|c|c|c|c|c|c|}
\hline \multirow[t]{2}{*}{ S. No. } & \multirow{2}{*}{$\begin{array}{c}\text { Fungicides / } \\
\text { Concentrations }\end{array}$} & \multirow[b]{2}{*}{ R.D. } & \multicolumn{4}{|c|}{ Colony diameter $(\mathrm{cm}) *$} & \multicolumn{4}{|c|}{ Per cent inhibition } \\
\hline & & & $\begin{array}{l}<500 \text { ppm } \\
\text { of R.D. }\end{array}$ & R.D. & $\begin{array}{l}>500 \mathrm{ppm} \\
\text { of R.D }\end{array}$ & mean & $\begin{array}{l}<500 \text { ppm } \\
\text { of R.D. }\end{array}$ & R.D. & $\begin{array}{c}>500 \\
\text { ppm of } \\
\text { R.D }\end{array}$ & Mean \\
\hline 1 & Thiram & $0.30 \%$ & $2.33(1.53)$ & $1.87(1.36)$ & $1.50(1.22)$ & $1.9(1.37)$ & 74.11 & 79.22 & 83.33 & 78.89 \\
\hline 2 & Captan & $0.30 \%$ & $2.33(1.53)$ & $1.87(1.36)$ & $1.50(1.22)$ & $1.9(1.37)$ & 74.11 & 79.22 & 83.33 & 78.89 \\
\hline 3 & Copper oxy chloride & $0.30 \%$ & $2.89(1.70)$ & $2.00(1.41)$ & $1.74(1.32)$ & $2.21(1.48)$ & 67.88 & 77.77 & 80.66 & 75.44 \\
\hline 4 & Mancozeb & $0.30 \%$ & $0.00(0.71)$ & $0.00(0.71)$ & $0.00(0.71)$ & $0.00(0.71)$ & 100.00 & 100.00 & 100.00 & 100.00 \\
\hline 5 & Chlorothalonil & $0.20 \%$ & $2.73(1.65)$ & $2.50(1.58)$ & $2.22(1.49)$ & $2.48(1.57)$ & 69.66 & 72.22 & 75.33 & 72.40 \\
\hline 6 & Carbendazim & $0.20 \%$ & $0.00(0.71)$ & $0.00(0.71)$ & $0.00(0.71)$ & $0.00(0.71)$ & 100.00 & 100.00 & 100.00 & 100.00 \\
\hline 7 & Hexaconazole & $0.20 \%$ & $0.00(0.71)$ & $0.00(0.71)$ & $0.00(0.71)$ & $0.00(0.71)$ & 100.00 & 100.00 & 100.00 & 100.00 \\
\hline 8 & Propiconazole & $0.10 \%$ & $0.00(0.71)$ & $0.00(0.71)$ & $0.00(0.71)$ & $0.00(0.71)$ & 100.00 & 100.00 & 100.00 & 100.00 \\
\hline 9 & $\begin{array}{l}\text { Carbendazim } 12 \%+\text { Mancozeb } \\
63 \%\end{array}$ & $0.20 \%$ & $0.00(0.71)$ & $0.00(0.71)$ & $0.00(0.71)$ & $0.00(0.71)$ & 100.00 & 100.00 & 100.00 & 100.00 \\
\hline 10 & Captan $70 \%+$ Hexaconazole $5 \%$ & $0.10 \%$ & $1.10(1.05)$ & $0.90(0.95)$ & $0.77(0.88)$ & $0.92(0.96)$ & 87.77 & 90.00 & 91.44 & 89.74 \\
\hline \multirow[t]{7}{*}{11} & Azoxystrobin & $0.10 \%$ & $4.18(2.04)$ & $4.00(2.00)$ & $3.48(1.86)$ & 3.89 (1.97) & 53.55 & 55.55 & 61.33 & 56.81 \\
\hline & Mean & & $1.41(1.19)$ & $1.19(1.11)$ & $1.02(1.05)$ & & 84.28 & 86.73 & 88.67 & \\
\hline & Check & & \multicolumn{3}{|c|}{$9.00(3.0)$} & & & & & \\
\hline & & \multicolumn{2}{|c|}{ Fungicide } & $\begin{array}{c}\text { Concentratio } \\
\mathbf{n}\end{array}$ & F X C & $\begin{array}{l}\text { Check vs } \\
\text { Others }\end{array}$ & & & & \\
\hline & $\mathrm{SEm} \pm$ & \multicolumn{2}{|c|}{0.01} & 0.01 & 0.02 & 0.02 & & & & \\
\hline & $\mathrm{CD}(\mathrm{P} \leq 0.05)$ & \multicolumn{2}{|c|}{0.03} & 0.02 & 0.06 & 0.06 & & & & \\
\hline & $\mathrm{CV}(\%)$ & \multicolumn{5}{|c|}{3.09} & & & & \\
\hline
\end{tabular}


Table.1 Fungicides evaluated against Alternaria macrospora in vitro

\begin{tabular}{|c|c|c|c|c|}
\hline $\begin{array}{l}\text { S. } \\
\text { No. }\end{array}$ & Name of the fungicide & $\begin{array}{l}\text { Recommended } \\
\text { dose }\end{array}$ & Trade name & $\begin{array}{c}\text { Active } \\
\text { ingredient }\end{array}$ \\
\hline 1 & Thiram & $0.3 \%$ & Thiram (Bayer) & $42-S \%$ WP \\
\hline 2 & Captan & $0.3 \%$ & Captaf (TATA) & $50 \% \mathrm{WP}$ \\
\hline 3 & Copper oxychloride & $0.3 \%$ & Blitox (TATA) & $50 \% \mathrm{WP}$ \\
\hline 4 & Mancozeb & $0.3 \%$ & Dithane M- 45 (Indofil) & $75 \% \mathrm{WP}$ \\
\hline 5 & Chlorothalonil & $0.2 \%$ & Kavach (Syngenta) & $75 \% \mathrm{WP}$ \\
\hline 6 & Carbendazim & $0.2 \%$ & Zoom (UPL) & $50 \% \mathrm{WP}$ \\
\hline 7 & Hexaconazole & $0.2 \%$ & Contaf (TATA) & $5 \% \mathrm{EC}$ \\
\hline 8 & Propiconazole & $0.1 \%$ & Tilt (Syngenta) & $25 \% \mathrm{EC}$ \\
\hline 9 & $\begin{array}{l}\text { Carbendazim 12\% + } \\
\text { Mancozeb 63\% }\end{array}$ & $0.2 \%$ & Saaf (UPL) & $75 \%$ \\
\hline 10 & $\begin{array}{l}\text { Captan } 70 \%+ \\
\text { Hexaconazole 5\% }\end{array}$ & $0.1 \%$ & Taaqat (TATA) & $80 \% \mathrm{WP}$ \\
\hline 11 & Azoxystrobin & $0.1 \%$ & Amistar (Syngenta) & $25 \% \mathrm{SC}$ \\
\hline
\end{tabular}

Interaction between fungicides and concentrations revealed that inhibition of growth at recommended dose of chemicals ranged between $55.55 \%$ in azoxystrobin and $100 \%$ in mancozeb, carbendazim, hexaconazole, propiconazole and carbendazim + mancozeb with inhibition by the next superior chemical captan + hexaconazole being $90.0 \%$. A similar trend was observed for radial growth of $A$. macrospora at $>500 \mathrm{ppm}$ and $<500 \mathrm{ppm}$ of recommended dose concentrations with obvious lesser growth (Fig. 2).

Among the different fungicides tested, thiram was found most effective against $A$. macrospora, with maximum growth inhibition (Gholve et al., 2014). Mancozeb and hexaconazole were the best fungicides for control of all the three species of A. alternata, A. macrospora and A. gossypina (Meena and Ratnoo, 2014). Ghazanfar et al., (2016) reported that mancozeb significantly reduced the growth of Alternaria solani compared to other treatments. Sanjeev et al., (2017) reported that among different fungicides tebuconazole showed significant reduction in mycelia growth of A. alternata in vitro. It was concluded that among the fungicides evaluated in vitro, mancozeb, carbendazim, hexaconazole, propiconazole and combination product of carbendazim $12 \%+$ mancozeb $63 \%$ at their recommended doses as well as below and above their recommended doses showed complete inhibition of mycelial growth of A. macrospora.

\section{References}

AICCIP. 2017. Annual Report (2016-17). ICAR-AICRP (Cotton) All India Coordinated Cotton Improvement Project, Coimbatore, Tamil Nadu.

Bhattiprolu, S.L. and Prasada Rao, M.P. 2009. Estimation of crop losses due to Alternaria leaf spot in cotton. J. Indian Soc. Cotton Improv., 14 (2): 151-154.

Chattannavar, S.N., Hosagoudar, G.N. and Ashtaputre. 2010. Crop loss estimation due to foliar diseases in cotton. Karnataka J. Agric. Sci., 23: 559 - 601.

Ghazanfar, M.U., Raza, W., Ahmed, K.S., Qamar, J., Haider, $\mathrm{N}$ and Rasheed, M.H. 2016. Evaluation of different 
fungicides against Alternaria solani (Ellis \& Martin) Sorauer cause of early blight of tomato under laboratory conditions. Int. J. Zoo. Stud., 1 (5): 812.

Gholve, V.M., Jogdand, S.M. and Suryawanshi, A.P. 2014. Evaluation of fungicides, botanicals and bioagents against Alternaria leaf blight caused by A. macrospora in cotton. J. Cotton Res. and Dev., 28 (2): 327-331.

Meena, P.K and Ratnoo, R.S. 2014. Efficacy of fungicides and phytoextracts against leafspot on cotton. Int. J. Agri. Sci., 10
(1): 115-118.

Nene, Y.L. and Thapliyal, P.N. 1993. Poison food technique. Fungicides in Plant Disease Control (2 ${ }^{\text {nd }}$ Edition). Oxford and IBH publication, New Delhi, India. 413-415.

Sanjeev, P.J., Mesta, R.K., Biradar, I.B., Sadanand, K.M and Ajjappalavar, P.S. 2017. Int. J. Curr. Microbiol. App. Sci., 6 (5): 495-504.

Vincent, J.M. 1927. Distortion of fungal hyphae in the presence of certain inhibitors. Nature, 59: 850.

\section{How to cite this article:}

Mohan Venkata Siva Prasad, B., S.L. Bhattiprolu, V. Prasanna Kumari and Anil Kumar, P. 2018. In Vitro Evaluation of Fungicides against Alternaria macrospora Causing Leaf Spot in Cotton. Int.J.Curr.Microbiol.App.Sci. 7(01): 2551-2557.

doi: https://doi.org/10.20546/ijcmas.2018.701.307 